\title{
Mean Flow and Variability in the Upper Portion of the East Sea Proper Water in the southwestern East Sea with APEX Floats
}

\author{
Homan Lee, Tae-Hee Kim, Ji-Ho Kim, Jang-Won Seo and Yang-Hoon Youn

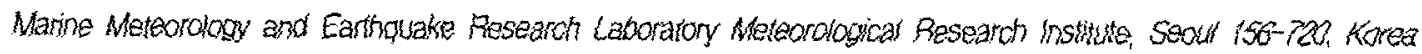 \\ Manuscrion received 7 November, 2003 ; accepted 2 January, 2004
}

Drift data from 17 Argo profiting floats in the East Sea ane used to understand the means flow and its variability in the upper portion of the East Sea Proper Water (UESPW) (around $800 \mathrm{~m}$ ). The flow penetrates into the Ulleung basin (UB) through two paths: an extension of the southward flowing of the North Korean Cold Water along the east coast of Korea and berween Ullewg lsland and Dok island, Kbows at $800 \mathrm{~m}$ are observed in the range of from 0.2 to $4.29 \mathrm{cms}-1$ and the variability in the north of the UBB is Sarger than that in the south of the UB. In the UB, cyclonic nows from 0.3 to $3.6 \mathrm{cms}-l$ are observed with the botton topography. We found that the mean kizetic energy (MKE) and the mean eddy kinetic energy (EKE) are 1.3 and $2.1 \mathrm{~cm} 2 \mathrm{~s}-2$ respectively.

Key worts: ARGO float, East Sea, Upper portion of the East Sea Proper Water, Mean kinetic energy, Mean eddy kinetic energy

\section{Introduction}

The deep water in the East Sea, called the East Sea Proper Water, is characterized by homogeneity in temperature and salinity. This characteristic makes it difficult to deduce the deep flow field from the dynarmics. Surde" and Senjyu and Sudo ${ }^{23}$ revealed that the Proper Water consists of at least two water masses: the upper portion and the deep water. The former, the upper portion of the East Sea Proper Water (UESPW), is defined as having at a 300-1000 $m$ depth with a potential density of $27.32 \sim 27.34$ $\mathrm{kgm}^{-3}$ as a mode water formed by winter convection off the primorye coast west of $136{ }^{\circ} \mathrm{E}$ between $40^{\circ} \mathrm{N}$ and $43 \mathrm{~N}$.

Recently, the CREAMS (Cjymlation Research of the Eist Asian Marginal Seas) project, first laumched in 1993, has intensified the oceanographic studies and detected the detailed subsurface structure of the

Corresponding Author : Homan Lee, Marine Moteorology and Earthquake Research Laboratory Meteorological Research Institute, Seoul 156-720, Korea

Phone : $482-2-847-2495$

E-mail : homannometrirekr water mass in the East Sea ${ }^{3-\{0\}}$. Chang et al. ${ }^{113}$, Lie et al. ${ }^{(2)}$, and Shin et al..$^{13\}}$ bave studied the mean circulation pantern in the East Sea from direct current measuresnents. And a schematic diagram of the deep water circulation in the East Sea was suggested by Shith et $2 l^{j a\rangle}$ from a number of deep sea current data directly observed by curnent meter moorings.

A new observation instrument, called the Autonomous Lagrangian Circulation Explorer (ALACE) ${ }^{15,267}$, is developed for the measurement of the curtent in the submerged water ${ }^{17)}$. Some reseasch has used neutrally buoyancy floats, for example, the RAfOS ${ }^{36}$ float, for deep cross equatorial flow in the Atlantic ${ }^{39}$, and ALACE for mid-deptith circulation in the tropical and South Pacific ${ }^{20)}$ and for intermediate depts ciscusiation in the tropical Atlantic ${ }^{21}$. In the East Sea park ${ }^{223}$ and Dancherkov et at ${ }^{23)}$ studied the ciscusation at $800 \mathrm{~m}$ from APEX, and Park et al. ${ }^{247}$ devised a new method to remove the errors in the estimated location and time from APEX, and estimated the velocity at the depth of $800 \mathrm{~m}$ after processing to minimize some types of errors.

In this paper, APEX (Autonomous Profiling 
Explorer) floats deployed by the Meteorological Research Institute (METRI) of the Korea Meteorological Administration (KMA) and the Korea Ocean Research \& Development Institute (KORDI) have been used to describe the mean flow and variability of the UESPW (at about 800 meter) in the southwest East Sea.

\section{Data}

As part of ARGO (Array for Real-time Geostrophic Oceanography) program, METRI launched three floats in 2001, and five floats in 2002 in the southwestern East Sea. Two of these floats drifted onto the continental shelf within the span of about three months and another two floats launched in 2002 ran out the Ulleung Basin (UB). And eleven floats, equipped with $\mathrm{SBE}-41$, were deployed by the Ministry of Maritime Affairs \& Fisheries (MOMAF) through KORDI. In this study, APEX data obtained in and around the UB within about two years have been analyzed (Table 1).

METRI-APEX floats were programmed to surface after six and one half-day periods of drift at a depth of approximately $800 \mathrm{dbar}$ but the KORDI APEX floats operated at $700 \mathrm{dbar}$ (Fig. 1). During their ascent to the surface from the parking depth, temperature and salinity profiles were obtained at preset pressures and transmitted during about a halfday surface period. The transmitted data including the float status information as well as the location information were collected from the ARGOS data transmission system ${ }^{25}$. Afterwards they were returned to the parking depth for the next mission.

\section{Results}

From the pattern of flow on Plate 1, it is

Table 1. Information of APEX floats and data used in this study

\begin{tabular}{|c|c|c|c|c|c|c|c|}
\hline $\begin{array}{c}\text { Argos ID } \\
\text { (WMO ID) }\end{array}$ & $\begin{array}{c}\text { Date of } \\
\text { Deployment }\end{array}$ & \multicolumn{2}{|c|}{$\begin{array}{l}\text { Location of } \\
\text { Deployment }\end{array}$} & $\begin{array}{c}\text { Period of } \\
\text { Data } \\
\text { (month) }\end{array}$ & $\begin{array}{c}\text { Drifting } \\
\text { depth } \\
\text { (m) }\end{array}$ & $\begin{array}{l}\text { Cycle } \\
\text { (day) }\end{array}$ & $\begin{array}{c}\text { Launched } \\
\text { by }\end{array}$ \\
\hline $24889(2900169)$ & Oct. 21,2001 & 37.17 & 130.48 & 3 & 800 & 7 & METRI \\
\hline $24890(2900170)$ & Oct. 22,2001 & 37.50 & 129.82 & 12 & 800 & 7 & $"$ \\
\hline $24892(2900171)$ & Oct. 22,2001 & 37.50 & 130.50 & 22 & 800 & 7 & $"$ \\
\hline $24680(5900193)$ & Aug. 2, 2002 & 38.28 & 129.40 & 11 & 800 & 7 & $"$ \\
\hline $24681(5900194)$ & Jul. 30,2002 & 38.10 & 130.37 & 11 & 800 & 7 & $"$ \\
\hline $24682(5900195)$ & Jul. 31,2002 & 37.59 & 131.51 & 11 & 800 & 7 & $"$ \\
\hline $24683(5900196)$ & Jul. 31, 2002 & 37.30 & 131.73 & 11 & 800 & 7 & $"$ \\
\hline $24851(5900197)$ & Jul. 31, 2002 & 36.50 & 131.09 & 3 & 800 & 7 & $"$ \\
\hline $23734(2900204)$ & Oct. 19,2001 & 38.52 & 129.50 & 21 & 700 & 10 & KORDI \\
\hline $18543(2900201)$ & Oct. 13,2001 & 37.30 & 131.43 & 10 & 700 & 10 & $"$ \\
\hline $18544(2900202)$ & Oct. 14,2001 & 37.23 & 131.90 & 19 & 700 & 10 & $"$ \\
\hline $18545(2900203)$ & Oct. 14,2001 & 37.30 & 131.72 & 16 & 700 & 10 & $"$ \\
\hline $04664(2900205)$ & $"$ & 36.00 & 130.00 & 21 & 700 & 10 & $"$ \\
\hline $04665(2900206)$ & $"$ & 36.17 & 130.17 & 17 & 700 & 10 & $"$ \\
\hline $046666(2900207)$ & $"$ & 36.17 & 130.33 & 21 & 700 & 10 & $"$ \\
\hline $04684(2900209)$ & Sep. 02, 2002 & 36.00 & 130.33 & 10 & 700 & 10 & $"$ \\
\hline $04252(2900225)$ & Sep. 02, 2002 & 36.00 & 130.5 & 10 & 700 & 10 & $"$ \\
\hline
\end{tabular}



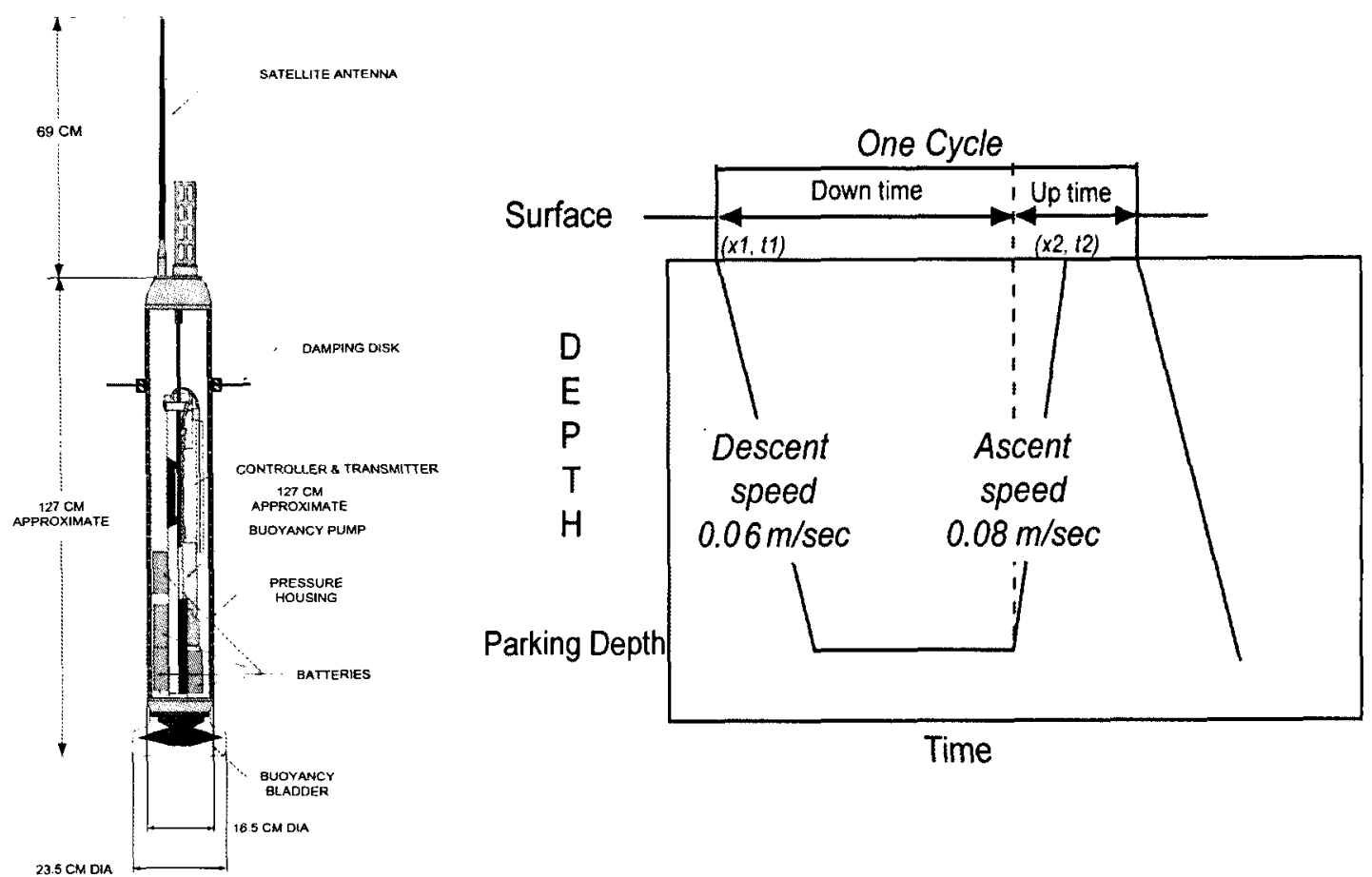

Fig. 1. APEX schematic (left panel) and an observation cycle of the profiling float (right).

apparent that flows at $800 \mathrm{~m}$ are spatially complex. Flows at $800 \mathrm{~m}$ generally are parallel to the coast with southward or southeastward flow and they are directed between Ulleung island and Dok island after sinking around the polar front ${ }^{10,26)}$.

Deep currents were observed at $620 \mathrm{~m}$ and $790 \mathrm{~m}$ depths off the mid-east coast of Korea from the end of August to November 1986. The deep currents were observed to be moving to the southeast with an average speed of about $3 \mathrm{cms}^{-1^{12)}}$. From Chang et al. ${ }^{11)}$, a strong deep mean flow of $6.2 \mathrm{cms}^{-1}$ was directed near the seabed ( about $1200 \mathrm{~m}$ ) and the mean kinetic energy (MKE) was larger than the eddy kinetic energy (EKE). In the southeastern part of the $\mathrm{UB}$, the flow of $1 \sim 8 \mathrm{cms}^{-1}$ was observed at a 1000 $m$ depth during the period from June 1999 to June 2000 and attained the maximum speed in winter ${ }^{13)}$. In this study the mean flows off the coast and east of Ulleung Island had a mean speed of $2.4 \mathrm{cms}^{-1}$ and $0.8 \mathrm{cms}^{-1}$ over the period of observation, respectively. In the UB, cyclonic flows from 0.3 to $1.6 \mathrm{cms}^{-1}$ were observed along with the bottom topography.
To compute the mean vectors and variability of the Lagrangian flow at 800 meters, we grouped the data in $0.5^{\circ} \times 0.5^{\circ}$ square grids. We calculated the vector averages and kinetic energy of the mean velocity on all boxes containing more than 2 vector values and represent the mean velocity in each box on Plate 2. The MKE and EKE were calculated in the same way as McClean et al. ${ }^{27)}$ did in the North Atlantic and Kundu and Allen ${ }^{28)}$ off the Oregon coast.

If the zonal velocity is denoted as $\mathrm{u}\left(\mathrm{cms}^{-1}\right)$, and the meridional velocity as $\mathrm{v}\left(c m s^{-1}\right)$, then MKE $\left(\mathrm{cm}^{2} \mathrm{~s}^{-2}\right)$ is

$$
\mathrm{MKE} \equiv \frac{1}{2}\left(\bar{u}^{2}+\bar{v}^{2}\right)
$$

where $\bar{u}, \bar{v}$ denotes a simple average taken over all the data in $0.5^{\circ} \times 0.5^{\circ}$ bins. The EKE is defined by

$$
\mathrm{EKE} \equiv \frac{1}{2}\left(u^{2}+v^{\prime 2}\right)
$$

where the prime indicates fluctuating velocity in 


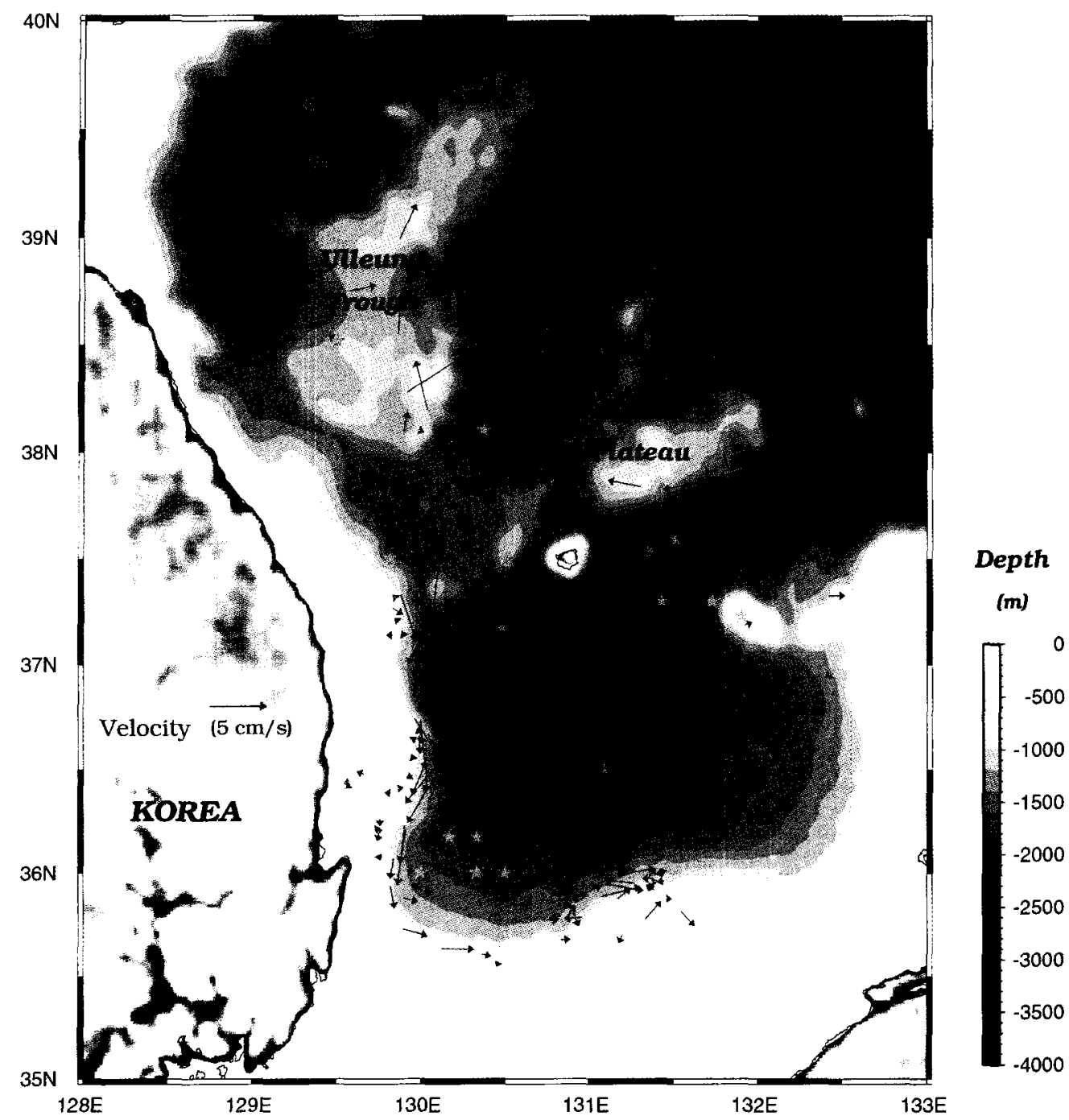

Plate 1. Bottom topography and current field at the intermediate depth (around 800 meter) observed by ARGO profiling floats. Deployment positions of floats are denoted by yellow asterisks.

bins.

The direction $(\theta)$, the axis of principal variability, was computed via

$$
\tan (2 \theta)=\frac{2 \overline{u^{\prime}}}{\overline{u^{\prime 2}}-\overline{v^{\prime 2}}}
$$

From Emery and Thomson ${ }^{29)}$, the magnitude of the variance along the major axis (minor axis) corresponds to a maximum (minimum) of $\mathrm{D}$,

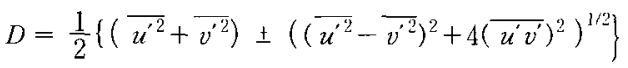

It was found that the mean MKE and mean EKE are 1.3 and $2.1 \mathrm{~cm}^{2} \mathrm{~s}^{-2}$ respectively. The variation of the deep currents in the northern part of the UB is larger than that in the southern part of the UB.

\section{Discussion and Conclusions}

The circulation of the UESPW was studied using profiling floats in the southwestern part of the East 
Mean Flow and Variability at the Upper Portion of the East Sea Proper Water in the southwestern East Sea with APEX Floats

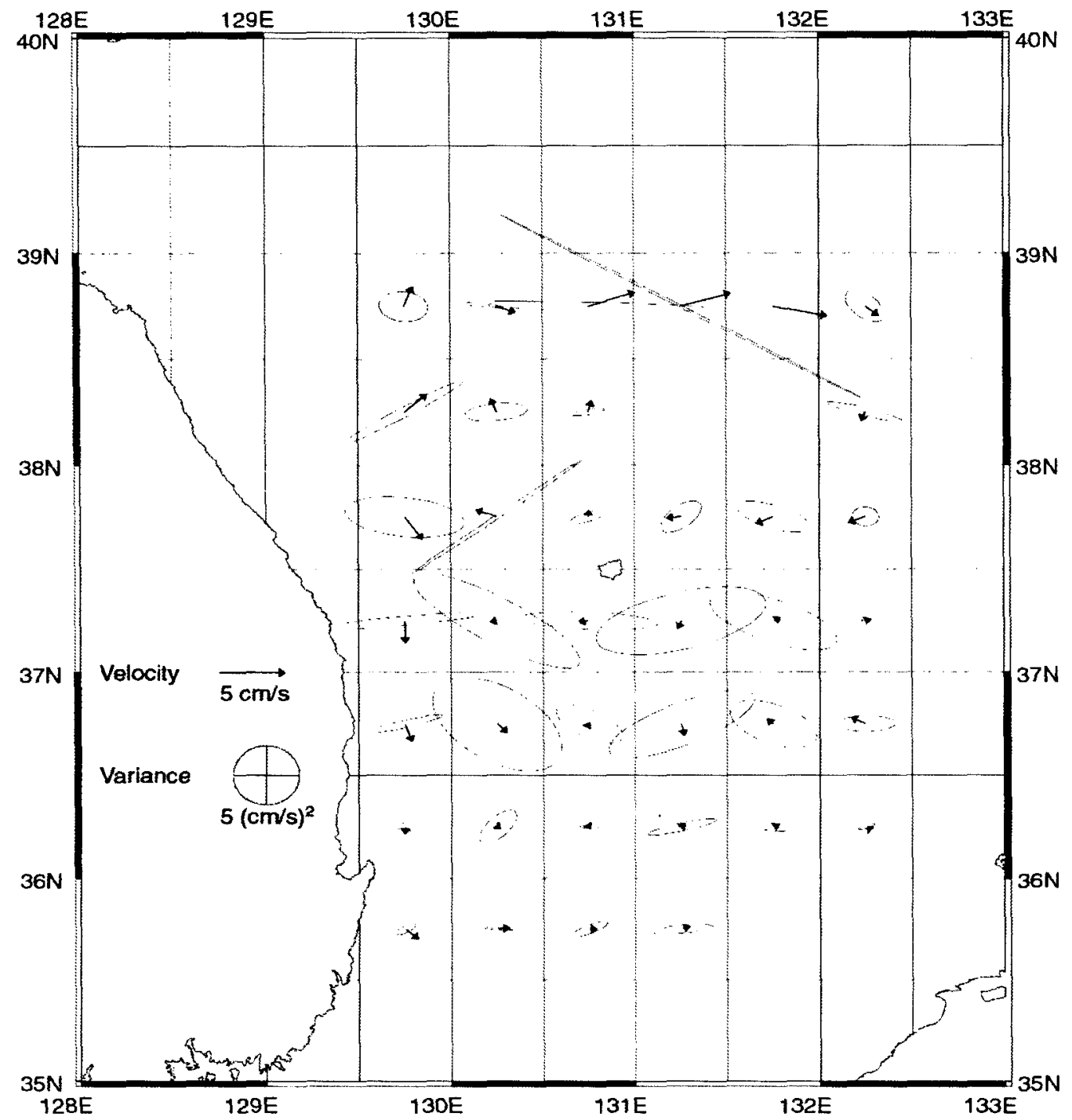

Plate 2. Mean velocity vectors $\left(\mathrm{cms}^{-1}\right)$ and principal standard variation ellipses $\left(\mathrm{cm}^{2} \mathrm{~s}^{-2}\right)$ at $800 \mathrm{~m}$ from $0.5^{\circ} \times 0.5^{\circ}$ binned.

Sea from November 2001 to July 2003.

The UESPW in the UB was formed from two intrusions: extending to the southward North Korea Cold Current flowing parallel to the coastline off the east coast of Korea, and westward flows, probably formed at the polar front parallel to $39-40{ }^{\circ} \mathrm{N}$, between Ulleung Island and Dok Island. The entering speeds were mean speeds of $2.4 \mathrm{cms}^{-1}$ and $0.8 \mathrm{cms}^{-1}$ in the northwestern and eastern part of the Ulleung basin, respectively. These passages are identical to those suggested by $\mathrm{Kim}$ et al. ${ }^{7}$ and the mean speed is a little weaker than that of Chang et al. ${ }^{9)}$ and Lie et al. ${ }^{10)}$ The UESPW entering the Ulleung basin flowed in the cyclonic direction along a bottom topography and had a mean speed of $0.9 \mathrm{cms}^{-1}$. It was found that the variation of the deep currents in the northern part of the UB is larger than that in the southern part of the UB.

\section{Acknowledgements}

We wish to thank the crew of R.V Gisang-2000 
for their dedication and full support during the deployment cruise. We are grateful to three anonymous reviewers for their critical reading and useful comments.

This study was carried out as a part of 'A Study on the Monitoring of the Global Ocean Variability with the ARGO Program' at the Meteorological Research Institute of the Korea Meteorological Administration.

\section{References}

1) Sudo, H., 1986, A note on the Japan Sea Proper Water, Prog. Oceanogr., 17, 313-336.

2) Senjyu, T. and H. Sudo, 1993, Water characteristics and circulation of the upper portion of the Japan Sea Proper Water, J. Mar. Sys., 4, 349-362.

3) Danchenkov, M. A., 2001, Preface for proceedings of CREAMS'2000 international symposium, Vlasivostok, $307 \mathrm{pp}$

4) Kim, C. H. and J. H. Yoon, 1999, A numerical modeling of the upper and the intermediate layer circulation in the East Sea, J. Oceanogr., 55, 327-345.

5) Kim, K., K. R. Kim, Y. G. Kim, Y. K. Cho, J. Y. Chung, B. H. Choi, S. K. Byun, G. H. Hong, M. Takematsu, J. H. Yoon, Y. Volkov and M. Danchenkov, 1996, New findings from CREAMS observations: water masses and eddies in the East Sea, J. Kor. Soc. Oceanogr., 31(4), 155-163.

6) Kim, K., Y. G. Kim, Y. K. Cho, M. Takematsu and Y. Volkov, 1999, Basin-to basin and year-to-year variation of temperature and salinity characteristics in the East Sea (Sea of Japan), J. Oceanogr., 55, 103-109.

7) Kim, Y. G., 1996, A study on the water characteristics and the circulation of the intermediate and deep layer of the East Sea, Ph. D. Thesis, Seoul National Univ., 113pp.

8) Kim, Y. G. and K. Kim, 1999, Intermediate waters in the East/Japan Sea, J. Oceanogr., 55, 123-132.

9) Takematsu, M., 1999, Foreward to CREAMS Volume, J. Oceanogr., 55, 101.

10) Yoon, J. H. and H. Kawamura, 2002, The formation and circulation of the intermediate water in the Japan Sea, J. Oceanogr., 58, 197-211.
11) Chang, K. I., N. G. Hogg, M. S. Suk, S. K. Byun, Y. G. Kim and K. Kim, 2002, Mean flow and variability in the southwestern East Sea, Deep-Sea Res., 49, 2261-2279.

12) Lie, H. J., M. S. Suk and C. H. Kim, 1989, Observations of southward deep currents off the East coast of Korea, J. Oceanol. Soc. Korea, 24, 63-68.

13) Shin, H. R, H. S. An, J. G. Lee, 2001, Deep water circulation in the south East Sea, Proc. 2001 Fall Meeting Kor. Earth Scien. Society, 54pp.

14) Shin, H. R, T. Senjyu, J. Y. Youn, H. S. An, S. K. Byun and J. G. Lee, 2002, The Circulation of the deep water in the East Sea, 1st Argo workshop proceeding, Jeju, Korea, 41-42pp.

15) Davis, R. E., J. T. Sherman and J. Dufour, 2001, Profiling ALACEs and other advances in autonomous subsurface floats, J. Atmos. Oceanic. Technol., 18, 982-993.

16) Davis, R. E., D. C. Webb, L. A. Regier and J. Dufour, 1992, The Autonomous Lagrangian Circulation Explorer (ALACE), J. Atmos. Oceanic. Technol., 9, 264-285.

17) Davis, R. E., P. D. Killworth and J. R. Blundell, 1996, Comparison of Autonomous Lagrangian Circulation Explorer ad fine resolution Antarctic model results in the South Atlantic, J. Geophys. Res., 101, 855-884.

18) Rossby, T., D. Dorson and J. Fontaine, 1986, The RAFORS System, J. Atmos. Oceanic Technol., 3, 672-679.

19) Swift, D. D and S. C. Riser, 1994, RAFOS Floats: Defining and Targeting Surfaces of Neutral Buoyancy, J. Atmos. Oceanic Technol., 11, 1079-1092.

20) Richardson, P. L. and W. J. Schmitz, 1993, Deep cross-equatorial flow in the Atlantic measured with SOFAR floats, J. Geophys. Res., 98, 8371-8387.

21) Schmid, C., R. L. Molinari and S. L. Garzoli, 2001, New observations of the intermediate depth circulation in the tropical Atlantic, J. Marin. Res., 59, 281-312.

22) Park, J. J., 2001, Deep Currents from APEX in the East Sea, Ms. D. Thesis, Seoul National Univ., 82pp. 

in the southwestern East Sea with APEX Floats

23) Danchenkov, M. A., S. C. Riser and J. H. Yoon, 2003, Deep currents of the central sea of Japan, Pacific Oceanogr., 1(1), 6-11.

24) Park, J. J., K. Kim, B. A. King and S. C. Riser, 2003, An advanced method to estimate deep currents from Profiling Floats, 1st Argo Science Workshop, Tokyo, Japan, 57pp.

25) CLS/Service, 1996, Argos, Users Manual 1.0.

26) Seung, Y. H., 1992, A simple model for separation for east Korean warm current and formation of north Korean cold current, J. Oceanol. Soc. Korea, 27(3), 189-196.
27) McClean, J. L., P. M. Poulain and J. W. Pelton, 2002, Eulerian and Lagrangian statistics from surface drifters and a high-resolution POP simulation in the North Atlantic, J. Physi. Oceanogr., 32, 2472-2491.

28) Kundu, P. K. and J. S. Allen, 1976, Some three-dimensional characteristics of low-frequency current fluctuations near the Oregon coast, J. Physi. Oceanogr., 6, 181-199.

29) Emery, W. S. and R. E. Thomso, 1998, Data Analysis Methods in zPhysical Oceanography, Pergamon, 624pp. 